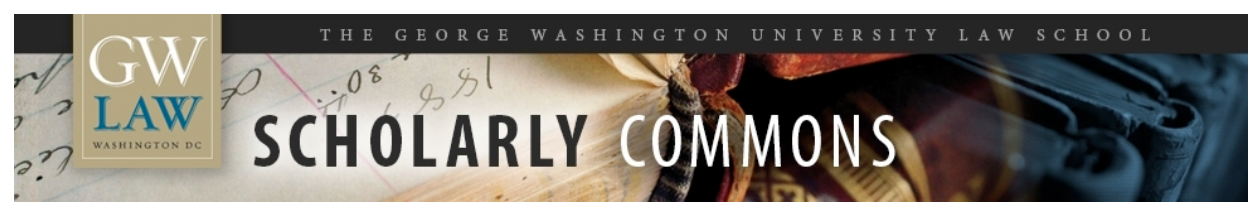

\title{
Citation to Legislative History: Empirical Evidence on Positive Political and Contextual Theories of Judicial Decision Making
}

\author{
Michael B. Abramowicz \\ George Washington University Law School, abramowicz@law.gwu.edu \\ Emerson H. Tiller
}

Follow this and additional works at: https://scholarship.law.gwu.edu/faculty_publications

Part of the Law Commons

\section{Recommended Citation}

Michael Abramowicz \& Emerson H. Tiller, Citation to Legislative History: Empirical Evidence on Positive Political and Contextual Theories of Judicial Decision Making, 38 J. LEGAL STUD. 419 (2009)

This Article is brought to you for free and open access by the Faculty Scholarship at Scholarly Commons. It has been accepted for inclusion in GW Law Faculty Publications \& Other Works by an authorized administrator of Scholarly Commons. For more information, please contact spagel@law.gwu.edu. 


\title{
Citation to Legislative History: Empirical Evidence on Positive Political and Contextual Theories of Judicial Decision Making
}

\author{
Michael Abramowicz and Emerson H. Tiller
}

\begin{abstract}
A BSTRACT
We present empirical evidence suggesting that political context-judicial hierarchy and judicial panel dynamics-influences an authoring judge's use of legislative history. Specifically, we find that to the extent that political ideology matters, a district court judge's choice of legislative history is influenced, albeit modestly, by (1) the political makeup of the overseeing circuit court and (2) the political characteristics of a judge's panel colleagues, as well as by the circuit court as a whole. These factors matter more than the authoring judge's own politicalideological connection to the legislators. Put differently, an authoring judge will have a greater tendency to cite legislative history by legislators who share political party affiliation with the colleagues and superiors of the authoring judge than legislators sharing the same political party affiliation as the authoring judge himself. These findings are consistent generally with positive political and contextual theories of judicial persuasion, collegiality, and strategic decision making.
\end{abstract}

\section{INTRODUCTION}

Judge Harold Leventhal famously described the invocation of legislative history as the equivalent of "looking over a crowd and picking out your friends" (Wald 1983, p. 214). The volume of legislative history is so great and varied that judges, some contend, could cite it selectively to advance their policy agendas (Scalia 1997). Practically speaking, judges interpreting statutes could routinely cite the statements of legislators who

MICHAEL ABRAmowicz is Professor of Law, George Washington University School of Law. EMERSON H. TILLER is J. Landis Martin Professor of Law and Business, Northwestern University School of Law. The authors thank Max Schanzenbach for helpful comments. 
share the same political perspective as the judges-that is, Democratappointed judges favoring citations of Democrat legislators and Republican-appointed judges favoring Republican legislators-with little cost to decision legitimacy and judicial reputation, as all would be available fodder from the legislative record.

It may be, however, that judges make such choices in a broader context than Judge Leventhal's statement suggests. Perhaps instead of looking for their own ideological friends in Congress, judges look for the ideological friends of their colleagues and superiors. In other words, instead of merely citing legislative history statements by legislators sharing the judge's own political-ideological preferences, judges (to persuade, to act collegially with, or to succumb to pressure from other judges) invoke legislative history from legislators who share the broad perspectives of the other judges with whom an opinion-writing judge must interact-specifically, panel colleagues or a higher supervising court with power to review. For example, a Democrat-appointed opinion-writing judge who sits on a panel with two Republican-appointed judges, or who is a district judge in a circuit in which most of the circuit judges are Republican appointed, may search out legislative statements made by Republican legislators that support the case outcome detailed in the judge's written opinion (or cite fewer Democrat legislators so as not to tag the decision as a "Democrat" position). In such a case, the choice of legislative citation may be driven more by collegiality or strategic calculation in an effort to persuade or assuage the other judges and courts than by an authoring judge's own preferences for citing likeminded legislators.

The judicial politics literature-in particular the attitudinal modelhas shown that judicial attitudes (typically liberal and conservative political ideologies) are powerful predictors of judges' votes and thus of case outcomes (Segal and Spaeth 1993; Pinello 1999). Positive political theory scholarship has shown how these attitudes may be advanced strategically when judges compete for policy, as often occurs in judicial panels, in judicial hierarchies, or under separation-of-powers conditions (Epstein and Knight 1997; Spiller and Spitzer 1992; Eskridge and Ferejohn 1992). And recent law and positive political theory scholarship illustrates how law itself-decision instruments and legal doctrines-is used strategically to facilitate or inhibit policy agendas when judges, courts, and other policy institutions interact (Spiller and Spitzer 1992; Cohen and Spitzer 1994; Spiller and Tiller 1996; Tiller 1998; Jacobi and Tiller 2007). The scholarship has evolved from simple measures of ideo- 
logical preference that reliably predicted case outcomes to a more nuanced perspective that considers how the pursuit of policy preferences is facilitated through institutional control mechanisms between policymaking bodies (Gely and Spiller 1990; Eskridge and Ferejohn 1992), the power and role of legal argument in judicial decision making (Tiller and Spiller 1999), and the contextual aspects of decision making within a collegial panel of judges (Cross and Tiller 1998; Sunstein, Schkade, and Ellman 2004; Cameron and Cummings 2003).

Following the work in positive political theory on doctrines and instruments, this article builds on the role of legal argument in politicalideological context by examining an important aspect of statutory interpretation-the citation of legislative history by the opinion-writing judge. Statutory interpretation is especially susceptible to analysis from a positive political theory perspective because of the interinstitutional dimensions of a court interpreting a legislature's pronouncements. Legislative history plays a key role for many judges in interpreting statutes, and the citation of legislative history in written opinions presents an opportunity for empirical analysis of how judges use an important form of legal argument to decide cases. There are implications for attitudinal, positive political, and contextual theories of decision making.

More concretely, our study considers whether a judge's citation to certain types of legislative history varies on the basis of the political characteristics of the opinion's audience (other judges), controlling for the opinion author's own political-ideological orientation. Specifically, we consider whether judges select legislative history that is particularly likely to appeal to those with whom he must contend, such as comembers of a judicial panel or judges on a higher court who might hear the case on review. This study does not aim to resolve whether the general use of legislative history is driven by political-ideological forces or instead fits with the more normative legal model of judicial decision making. It would be no surprise if use of legislative history for the most part fits the normative legal model (that is, attempting to interpret statutes in accordance with legislative intent), especially in areas with low political salience. But to the extent that political ideology does matter, we ask whether the evidence fits a model of judges citing their "legislative friends" (same-party legislators) to advance their own policy agenda or whether the evidence supports a more complex model of judges citing the legislative friends of their colleagues and supervisors. Evidence of the latter would be consistent with positive political or contextual theories of judicial decision making. 
In Section 2 of this article, we briefly review various models of judicial decision making offered by legal and judicial politics scholars and assess their implications for citations to legislative history. In Section 3, we present our empirical analysis. The evidence suggests that the invocation of legislative history by federal judges is related to political context. Specifically, although we find little evidence that a judge's own putative ideology affects whether he is more likely than the average judge to cite Republican or Democrat legislators, we find statistically significant evidence of hierarchy and panel contextual effects on an opinion-writing judge's decision of what legislative history to cite. In other words, the political-ideological characteristics of a judge's colleagues and supervisors matter in determining what legislative history an opinion-writing judge will cite. Section 4 provides discussion, and we conclude in Section 5 with suggestions for further exploration.

\section{THEORETICAL BACKGROUND}

\subsection{Legal Theory and Selective Citation}

The claim that judges might selectively, and even strategically, choose among various arguments is a familiar one, particularly in the context of legislative history. As mentioned above, Judge Leventhal described the invocation of legislative history as the equivalent of "looking over a crowd and picking out your friends." Similarly, Justice Antonin Scalia argues that legislative history provides "something for everyone" and that it can be "relied upon or dismissed with equal plausibility" and facilitates decisions "based upon the courts' own policy preferences" (Scalia 1997, pp. 35-37). Because there may be legislative history on both sides of an issue, consideration of legislative history might enable a judge to support either side, perhaps even when the text of the statute points unambiguously in only one direction.

An implication of the Leventhal and Scalia views is that judges should be more likely to cite legislative history approvingly when it advances the judge's personal policy preferences. From that perspective, one would expect such legislative history to come mainly from legislators who share similar political-ideological preferences with the citing judge. But as legal issues and political policy preferences do not uniformly align in every case, and because of the abundance of legislative history from both sides of the political spectrum on most congressional acts, there exist occasions when a judge could cite legislative history coming from a legislator of 
a different political orientation and when such citations would still be consistent with the judge's preferred outcome in the given case. Consequently, the fact of a judge occasionally citing a legislator not sharing a similar political orientation (a Democrat-appointed judge citing legislative history from a Republican legislator, for example) would not be inconsistent with Scalia's observation. There is nothing from this perspective, however, suggesting that such citation should be related to the political-ideological leanings of an authoring judge's colleagues or higher court superiors (that is, the broader political-ideological context of judicial decision making), the condition we explore in this study.

\subsection{Political Science and Selective Citation}

The dominant view of judicial decision making in the political science literature-the attitudinal model-holds that the political beliefs and attitudes of judges measurably affect their voting choices (Segal and Spaeth 1993). The studies supporting this view are now legion (Pinello 1999), seriously undercutting at least the strong-form version of the more normative legal model (in which judges are viewed as neutral and nonideological decision makers). The empirical research also shows that a judge's political party affiliation, as represented by the party of the appointing president, is a good proxy for ideological or attitudinal differences that impact the judge's voting in cases (Revesz 1997; Pinello 1999).

The attitudinal model makes predictions about the outcomes of cases (who wins, who loses), not about the content of opinions (doctrines, instruments, legislative history, and so on). The attitudinal model thus does not produce clear testable predictions about citations to legislative history. At least stated in its strongest form, the model would appear to deny that legislative history in fact motivates judicial decision making at all. Attitudinal theory, however, would be consistent with findings of ideological influences on legislative history citation by judges. Citation could be merely a form of post hoc rationalization, in which case the attitudinal model might predict that judges would tend to cite legislative history consistent with their policy preferences over outcomes. Consequently, one might expect to see liberal jurists citing liberal legislators and conservative jurists citing conservative legislators.

More recently, law and positive political theory scholarship has looked beyond case outcomes to consider aspects of the reasoning underlying decisions, showing how some choices may reflect strategic attempts to affect policy. Tiller and Spiller (1999), for example, posited that a judge's choice of relying on factual, rather than legal, grounds to 
resolve a case can serve to protect the judge's policy choice preferences from higher court review and reversal. At least two empirical papers found support for that theory, one in the context of environmental decisions (Smith and Tiller 2002) and the other in criminal sentencing cases (Schanzenbach and Tiller 2007). Although the literature has identified a strategic policy dimension to the more obvious legal reasoning tools, such as doctrines and legal instruments, the literature has not yet explained more microlevel aspects of opinion reasoning, such as why an opinion emphasizes certain facts, precedents, or legislative history rather than others. Given a particular final case outcome, there is no immediate legal consequence to whether a judge supported that outcome by citing to legislative history created by a legislator of one party or the other.

Nonetheless, citation of legislative history may be a product of political-contextual dimensions of judicial decision making, motivated by either strategic play or the pressures of collaborative and hierarchical decision-making practices. And such choices may ultimately impact the final policy outcome selected by courts. This possibility finds some support from recent positive political and contextual effects theories that suggest that particular characteristics of judges affect the decisions of other judges deciding cases with them. Cross and Tiller (1998), for example, show that a three-judge panel of the federal circuit courts is less likely to vote in accordance with the majority's presumed ideological preferences when there is at least one judge on the panel who does not share the authoring judge's presumed preferences (such as a Democrat appointee with two Republican appointees) and with whom judicial precedent stands in support. This third judge acts as a potential whistleblower who induces the opinion author to follow the law. Sunstein, Schkade, and Ellman (2004) found related interaction effects in a range of doctrinal settings. On cases concerning issues such as affirmative action, piercing the corporate veil, and environmental regulation, they found that while the party of the appointing president is "a fairly good predictor of how individual judges will vote[,] . . the political party of the president who appointed the other two judges on the panel is at least as good a predictor of how individual judges will vote” (p. 305). Sunstein, Schkade, and Ellman noted that there are multiple possible explanations for the interaction effects, including persuasion and collegiality.

Cameron and Cummings (2003) studied the effect of racial, gender, and ideological diversity on judicial decision making in affirmative action cases. Their analysis attributed the contextual effects entirely to the 
presence of diverse members sitting on the panel rather than to persuasion efforts by any given judge on the panel. A separate study by Farhang and Wawro (2004) identified similar contextual effects, showing that the presence of a single woman on a judicial panel had a significant effect on the votes of the other panel members. Whether a female judge actually wrote the opinion did not have a statistically significant effect on the votes of either that judge or the other judges. Farhang and Wawro concluded that the contextual effect occurs because of the diversity on the panel and not necessarily as a result of the other judges' being persuaded by the opinion author in particular.

For the most part, contextual effects studies have focused on data concerning judges' votes on case outcomes. Judges are engaged in a deliberative enterprise, however, so contextual effects also may occur at the level beneath judges' votes on outcomes, in the microlevel legal reasoning that judges use to support the resolutions that they reach. If political-ideological contextual effects exist and lead judges to adjust their votes (in both direction and degree), we might expect authoring judges who respond to other judges, or even seek to persuade other judges, to adopt reasoning tailored to those judges' political orientations, including the citation to legislative history that appeals to them. In short, we should observe that political-ideological context matters below the surface of votes on case outcomes.

\section{EMPIRICAL ANALYSIS}

\subsection{Testable Implications}

First, we test the existence of an author ideology effect-that is, when an authoring judge, whether on a district or appellate court, cites to legislative history, is he more likely to cite a Republican legislator if he was appointed by a Republican president or Democrat legislator if he was appointed by a Democrat president? This is the most tentative hypothesis, and it is not a direct prediction of the positive political or contextual effects models; it is, however, a possible implication of the attitudinal model, as it looks solely to the authoring judge's own political ideology. As explained above, a judge may cite like-minded (same-party) legislators as part of a post hoc rationalization of a nonstrategic, yet political-ideologically motivated, policy outcome. On the other hand, it is also possible that a judge may seek to cite opposite-party legislators as a means of making his opinion appear not to be driven by ideology. 
We further test whether, in circuit court panels, the author ideology effect is more pronounced in concurring and dissenting opinions. A concurring or dissenting judge has failed to persuade other judges on the panel and thus may be more likely to express his own ideological preferences in selecting what legislative history, and which legislator, to cite. ${ }^{1}$

Second, we test the existence of a hierarchy effect-that is, whether a judge's pattern of citation to legislative history is likely to be correlated with the identities of superior judges who may review the judge's work. In particular, we test the proposition that when a district court judge cites to legislative history, the probability that the citation is to a Republican legislator will be greater the larger the proportion of Republican-appointed judges on the reviewing court, regardless of the political ideology of the opinion-writing judge. ${ }^{2}$ Similarly, we test the proposition that when a circuit court judge cites to legislative history, the probability that the citation is to a Republican legislator will be greater the larger the proportion of Republican-appointed judges on the potential en banc court.

Third, we test the existence of a panel effect. That is, a judge's pattern of citation to legislative history is likely to be correlated with the identities of the other judges on the panel. In particular, we test the proposition that when an appellate judge cites to legislative history, the probability that the citation is to a Republican legislator will be greater the larger the proportion of Republican-appointed judges on that panel, and similarly, the probability that a citation is to a Democrat legislator will be greater the larger the proportion of Democrat-appointed judges on that panel.

We tested all of these effects both over the entire data set and over subsets of the data set identified by controls for subject matter (on the basis of whether they appeared a sufficient number of times in the opinion). The data sets for subject matter controls were sufficiently small, however, that the effects were generally not statistically significant. As a result, all of the results reported here are over all applicable cases.

1. On the other hand, a concurring or dissenting judge may be writing with another audience in mind-the en banc court-and may seek to persuade the majority on that court with legislative history targeted toward its preferences. This possibility is more consistent with political context explanations and is explored in our tests of hierarchy effects below.

2. We will test the hierarchy effect only on district court and appellate court decisions because the rarity of changes in the composition of the Supreme Court makes it difficult to identify associations between Supreme Court composition and lower court decision making. 


\subsection{Data and Summary Statistics}

Our data derive from the LEXIS database of decisions by federal courts in the United States. We downloaded all cases decided from 1950 through 2003 that contained the phrase "Cong. Rec.,"3 the appropriate citation form for the Congressional Record. Our analysis is thus only to this form of legislative history, not to other forms such as committee reports. Although committee reports often provide critical legislative history for any given piece of legislation, a committee report generally reflects the views of the committee as a whole rather than a particular Democrat or Republican legislator.

The data set included from each opinion data identifying the court issuing the opinion, the judge authoring the opinion (or the first-listed judge for jointly authored opinions), the number of citations to legislative history, and the proportion of legislative history citations that were to Republican or Democrat legislators. Cases in which we were unable to determine the identity of all judges on the panel were excluded from the database. ${ }^{4}$ We classified an opinion as a majority opinion if it was the first opinion in a case; all other opinions (concurrences and dissents) were classified as nonmajority opinions.

Data identifying the president appointing a particular judge were drawn from the Federal Judges Biographical Database. ${ }^{5}$ That source was also used to calculate the proportion of Republican appointees among active judges on the court of appeals for that circuit at the end of the year in which a case was decided. We assigned particular legislators to particular citations by examining parentheticals following citations, which often contained text such as "remarks of Rep. Smith." In the absence of such an identification, we searched in the 1,000 characters preceding the citation for an identification of a legislator (either a member of the House or of the Senate). Although this approach may admit occasional errors, we have no reason to believe that these errors would

3. A computer program developed in Visual Basic for Applications parsed the downloaded cases, and a macro in the SAS statistical programming language accomplished further processing.

4. Occasionally, the wording identifying the judges was nonstandard or a judge's name was misspelled and the computer program was unable to make a certain identification. Such cases were excluded from the data set.

5. Federal Judicial Center, Judges of the United States Courts: Biographical Directory of Federal Judges (http://www.fjc.gov/history/home.nsf/judges_frm!OpenFrameSet). (1997).

6. The computer program looked up individual legislators by consulting McKibbin 
bias our results. Where no legislator could be identified, because either there was no reference to a legislator or a reference did not uniquely identify a legislator in the relevant session of Congress, the citation was ignored. Cases with no citations successfully processed were omitted from the data set, and citations that could not be processed were omitted as well. ${ }^{\text {? }}$

The result of the processing was a data set consisting of data covering 6,524 opinions, comprising in total 13,031 citations to legislative history. The data could be analyzed at the citation and opinion levels. We classified an opinion as citing Republican legislators if at least half of the identified citations were to Republican legislators and as citing Democrat legislators otherwise.

In the analyses that follow, we rely primarily on opinions as the unit of analysis. Because legislative history generally figures more prominently in the analysis of a case when there are more legislative history citations, in each regression we weighted the observations with a variable set equal to the total number of processed citations in the opinion. We begin by considering the political ideology (attitudinal) effect, then the hierarchy effect for district court judges, and then both the hierarchy and panel effects for appellate judges.

3.2.1. Ideology Effect. Table 1 provides some summary statistics showing the number of citations and opinions by Democrat-appointed $\left(U_{\mathrm{D}}\right)$ and Republican-appointed $\left(J_{R}\right)$ judges citing to Democrat $\left(L_{D}\right)$ or Republican $\left(L_{\mathrm{R}}\right)$ legislators. The data make clear that there are considerably more citations to Democratic legislative history than to Republican legislative history by judges of both political parties, presumably because of the Democrats' general domination of Congress from the New Deal period onward.

The raw data suggest that differences in citation patterns between Democrat- and Republican-appointed judges are slight and thus that the author ideology effect is relatively weak. (We test the statistical significance of the author ideology effect directly in the subsequent sections in conjunction with tests of other effects.) There is a 1.4-percentagepoint difference in the frequency with which Democrat-appointed and Republican-appointed judges' cite Democrat or Republican legislative history when measured by citations and a 1.5 -percentage-point difference when measured at the opinion level.

7. We explain in Section 3 the effect on our analyses of the choice not to cite legislative history. 
Table 1. Citations and Opinions with Citations, by Citing Judge and Cited Legislator(s)

\begin{tabular}{|c|c|c|c|c|c|}
\hline & \multicolumn{2}{|c|}{$L_{\mathrm{D}}$} & \multicolumn{2}{|c|}{$L_{\mathrm{R}}$} & \multirow[b]{2}{*}{ Total } \\
\hline & $N$ & $\%$ & $N$ & $\%$ & \\
\hline $\begin{array}{l}\text { Citations: } \\
J_{\mathrm{D}} \\
J_{\mathrm{R}}\end{array}$ & $\begin{array}{r}3,991 \\
3,842 \\
\end{array}$ & $\begin{array}{l}60.8 \\
59.4\end{array}$ & $\begin{array}{l}2,570 \\
2,628 \\
\end{array}$ & $\begin{array}{l}39.2 \\
40.6\end{array}$ & $\begin{array}{l}6,561 \\
6,470 \\
\end{array}$ \\
\hline $\begin{array}{l}\text { Total } \\
\text { Opinions with citations: } \\
J_{\mathrm{D}} \\
J_{\mathrm{R}}\end{array}$ & $\begin{array}{l}\overline{7,833} \\
1,885 \\
1,902 \\
\end{array}$ & $\begin{array}{l}60.1 \\
\\
58.8 \\
57.3\end{array}$ & $\begin{array}{l}5,198 \\
1,322 \\
1,415 \\
\end{array}$ & $\begin{array}{l}39.9 \\
41.2 \\
42.7\end{array}$ & $\begin{array}{r}3,207 \\
3,317 \\
\end{array}$ \\
\hline Total & 3,787 & 58.0 & $\overline{2,737}$ & 42.0 & 6,524 \\
\hline
\end{tabular}

The raw data, however, tell us little about political context-that is, whether citation to particular legislators is conditioned on judicial hierarchy or panel effects.

3.2.2. Hierarchy Effect. Consider potential hierarchy effects. We begin with citations by district court judges. Each observation represents an individual judicial opinion, and the dependent variable reflects whether the citations were to Republican legislators (one) or to Democrat legislators (zero). ${ }^{8}$ The independent variables control for the judge's own party affiliation as well as the party composition of the reviewing circuit court (the hierarchy relationship). The variable $\% J_{R}$ on Supervising Circuit represents the proportion of active Republican-appointed judges on the supervising circuit court as of the end of the year in which the case was decided. We include in this regression and all subsequent regressions fixed-effects variables for the decades in which the cases were decided $^{9}$ and for the circuits (in the case of Table 3, the circuits in which the district courts were located). In addition, we include variables representing the party in control of the Senate (for example, $S_{\mathrm{R}}$ equals one if Republicans and zero if Democrats), House $\left(H_{R}\right)$, and presidency $\left(P_{R}\right)$

8. We checked the robustness of our approach by also running all regressions as ordinary least squares regressions in which the dependent variable represented the percentage of citations to Republican legislators. This does not materially change our principal results.

9. We included variables representing the $1970 \mathrm{~s}, 1980 \mathrm{~s}, 1990 \mathrm{~s}$, and $2000 \mathrm{~s}$. When we also attempted to include a dummy variable representing the 1960 s, thus differentiating those cases from cases decided in the 1950 s, many of our regressions failed to converge. We thus eliminated the 1960 s variable, effectively grouping the 1950 s and 1960 s. 
Table 2. Probit Test of Ideology and Hierarchy Effects: District Courts

\begin{tabular}{lcc} 
& \multicolumn{1}{c}{ Estimate } & $p$ \\
\hline Intercept & $-.26(.15)$ & $<.0001^{*}$ \\
$J_{\mathrm{R}}$ & $-.031(.046)$ & .068 \\
$\% J_{\mathrm{R}}$ on Supervising Circuit & $.23(.17)$ & $.0002^{*}$ \\
$S_{\mathrm{R}}$ & $.076(.063)$ & $.0011^{*}$ \\
$H_{\mathrm{R}}$ & $.25(.092)$ & $<.0001^{*}$ \\
$P_{\mathrm{R}}$ & $.053(.054)$ & $.0079^{*}$ \\
\hline
\end{tabular}

Note. Decade and circuit fixed-effects variables are not listed; the following were statistically significant, with coefficients in parentheses: 5 th $\mathrm{Cir}$ cuit $\left(.11^{*}\right)$, 6th Circuit $\left(.086^{*}\right)$, 8th Circuit $\left(-.12^{* *}\right)$, 10th Circuit $\left(.11^{*}\right)$, and 11 th Circuit $\left(.21^{* *}\right) . N=1,947$; pseudo- $R^{2}=.069$. Estimates reported are marginal effects; relative standard errors are in parentheses.

${ }^{*} p<.05$.

$* * p<.01$.

at the time of the legislative history citation. ${ }^{10}$ Table 2 presents our probit analysis. The dependent variable is $L_{\mathrm{R}}$ (at least half of citations in the opinion are to Republican legislators), and the principal explanatory variables are $J_{R}$ (whether the authoring judge is Republican appointed) and $\% J_{R}$ on Supervising Circuit, the percentage of Republican-appointed judges on the supervising circuit.

We find that a district court judge's own political ideology $\left(J_{R}\right)$ is not quite significant in deciding what type of legislator will be cited. In other words, increasing the likelihood of a Republican-appointed district court judge does not increase the likelihood of a citation being made to a legislative statement by a Republican legislator. Indeed, the sign on the coefficient is negative, which is consistent with the theory that district court judges may seek to mask their own political predilections through opposite-party citation. The political ideology of the overseeing circuit is statistically significant $(p<.01)$, however, and the effect is in the expected direction for the hierarchy effects hypothesis. As the proportion of Republican appointees on the supervising circuit increases, district court judges are more likely to cite to legislative history from Republican legislators. The .23 coefficient indicates that for this group, a marginal 1 -percentage-point increase in the Republican composition of the supervising circuit produces a .23-percentage-point increase in the prob-

10. We omitted a small number of observations in which our computer parsing program was unable to determine the year of the citation. We also ran additional tests omitting these variables and including only some of these variables, and our results were qualitatively similar. 
ability that an opinion citing to legislative history will cite predominately to Republican legislators. Unsurprisingly, our fixed-effects variables for the composition of the Senate and the House and the party controlling the presidency at the time of the legislative history were statistically significant in the expected direction; judges are more likely to cite statements by legislators who were in the majority or in the president's party at the time the legislation was passed. This appeared especially true for the House, whose coefficient was as large as the makeup of the supervising court.

\subsubsection{Panel Effects. Next, we consider panel effects in decisions of the} U.S. courts of appeals, while continuing to control for both author ideology effects and, given the possibility of en banc review, hierarchy effects. We consider all citations to legislators by circuit court judges sitting in three-judge panels. Table 3 presents the results of our probit analysis, with independent variables representing the political affiliations of the opinion author, the remaining judges on the three-judge panel, and the remainder of the circuit. ${ }^{11}$

Table 3 shows that as the rest of the panel shifts from Democrat appointees to Republican, the opinion-writing judge employs relatively more citations to Republican legislators. This is so whether the opinion author is a Democrat- or Republican-appointed judge. The effect is statistically significant $(p<.05)$, once again in the direction expected by positive political and contextual theories, although quite small. The variable representing the proportion of Republican appointees on the circuit as a whole is not statistically significant in this specification, which suggests no hierarchy effect for opinions by panel members. Again, there is no author ideology effect (and the magnitude of the coefficient on $J_{R}$ points in the opposite of the expected direction). ${ }^{12}$

The above analysis does not indicate whether the increase in citation to same-party legislators can be explained primarily as a result of cases

11. We calculated this by subtracting the number of Democrats and Republicans on the panel from the number of Democrats and Republicans in the circuit as a whole. In some cases, the variable representing the proportion of judges in the rest of the circuit may be slightly inaccurate, for example, when there are visiting judges on a three-judge panel, but there is no reason to believe that this should bias our results.

12. To assess the robustness of these results, we also ran a probit regression involving all circuit court cases, including en banc cases. The variable representing the percentage of Republican appointees on the remainder of the panel continued to have the expected sign and to be statistically significant $(p<.01)$. The author ideology variable remained statistically insignificant. 
Table 3. Probit Test of Ideology, Panel, and Hierarchy Effects: Circuit Court Three-Judge Panel Opinions

\begin{tabular}{lll}
\hline & \multicolumn{1}{c}{ Estimate } & \multicolumn{1}{c}{$p$} \\
\hline Intercept & $-.20(.15)$ & $.0001^{* *}$ \\
$J_{\mathrm{R}}$ & $-.021(.035)$ & .11 \\
$\% J_{\mathrm{R}}$ on Rest of Panel & $.035(.049)$ & $.047^{*}$ \\
$\% J_{\mathrm{R}}$ on Rest of Circuit & $.012(.088)$ & .71 \\
$S_{\mathrm{R}}$ & $.068(.047)$ & $<.0001^{*}$ \\
$H_{\mathrm{R}}$ & $.26(.063)$ & $<.0001^{*}$ \\
$P_{\mathrm{R}}$ & $.067(.037)$ & $<.0001^{*}$ \\
\hline
\end{tabular}

Note. Decade and circuit fixed-effects variables are not listed; the following were statistically significant, with coefficients in parentheses: 1980 s $\left(-.084^{*}\right)$, 2nd Circuit $\left(.094^{*}\right)$, 3rd Circuit $\left(.13^{* *}\right)$, 4th Circuit $\left(.11^{*}\right)$, 6th Circuit $\left(.16^{* *}\right)$, 10th Circuit $\left(.15^{* *}\right)$, and 11 th Circuit $\left(.16^{* *}\right) . N=3,146$; pseudo- $R^{2}=.074$. Estimates reported are marginal effects; relative standard errors are in parentheses.

$p<<.05$.

* $p<.01$.

in which one other judge on the panel is of the same party as the authoring judge or of cases in which both other judges on the panel are of the same party as the authoring judge. To address this, Table 4 reports a regression in which the dependent variable is one whenever an opinion cites primarily to legislators of the same political party as the authoring judge, that is, when $J_{R}=1$ and $L_{R}=1$ or $J_{D}=1$ and $L_{D}=1$. With this approach, we can no longer identify ideology effects, but we can straightforwardly assess the effects of panel composition. The regression includes two binary explanatory varjables (in addition to the fixed-effects variables from the previous regressions), including whether the other two judges are both of the same party as the author (for example, this variable would be one given a Republican-authored opinion if and only if the other two judges were both Republican), and whether the other two judges are both of the opposite party from the author (for example, this variable would be one given a Republican-authored opinion if and only if the other two judges were both Democrats). Thus, the baseline case is the one in which one of the two other panel members is of the same party as the authoring judge, and we use the regression to measure deviations from this baseline.

In this regression, the percentage of judges on the rest of the circuit who have the same political ideology as the opinion author is positive and significant $(p<.01)$. This appears to confirm the existence of a hierarchy effect in panel decisions, although the effect is modest. Table 3 
Table 4. Probit Analysis of Panel and Hierarchy Effects: Circuit Court Three-Judge Panel Opinions

\begin{tabular}{lccc}
\hline & \multicolumn{2}{c}{ Estimate } & \multicolumn{1}{c}{$p$} \\
\hline Intercept & -.46 & $(.15)$ & $<.0001^{* *}$ \\
Other Judges Same Party as Author & .085 & $(.039)$ & $<.0001^{* *}$ \\
Other Judges Different Party from Author & $-.0021(.041)$ & .87 \\
$\% J$ on Circuit of Same Party as Author & $.089(.070)$ & $.0006^{* *}$ \\
$S_{\mathrm{s}}$ & $.049(.045)$ & $.0034^{*}$ \\
$H_{\mathrm{s}}$ & .25 & $(.047)$ & $<.0001^{* *}$ \\
$P_{\mathrm{s}}$ & $.075(.036)$ & $<.0001^{*}$ \\
\hline
\end{tabular}

Note. Decade and circuit fixed-effects variables are not listed; the following were statistically significant, with coefficients in parentheses: 1970 s $\left(.096^{* *}\right), 1980 \mathrm{~s}\left(.074^{* *}\right), 1990 \mathrm{~s}$ $\left(.11^{* *}\right)$, 1st Circuit $\left(.15^{* *}\right)$, 3rd Circuit $\left(.14^{* *}\right)$, 4th Circuit $\left(.18^{* *}\right)$, 5th Circuit $\left(.14^{* *}\right)$, 7 th Circuit $\left(.20^{* *}\right)$, 8th Circuit $\left(.17^{* *}\right)$, 9th Circuit $\left(.14^{* *}\right)$, and D.C. Circuit $\left(.11^{*}\right) . N=3,146$; pseudo- $R^{2}=.10$. Estimates reported are marginal effects; relative standard errors are in parentheses.

$* p<.05$.

${ }^{*} p<.01$.

obscured this effect, because circuit composition changes only slowly, and we include fixed-effects variables for both circuits and decades. ${ }^{13}$ The specification of Table 4 allows for more variability in panel composition, because the same-party circuit composition will change from one case to another depending on whether the opinion author is a Democrat or Republican.

Meanwhile, Table 4 helps elaborate on the nature of the panel effects first observed in Table 3. The variable Other Judges Same Party as Author is significant and in the expected direction, indicating that politically unified panels are the outliers in their citation trends $(p<.05)$. The variable Other Judges Different Party from Author was not statistically significant, indicating that there is no statistically significant difference from the baseline case in which at least one judge is of a different party from the author. That is, it does not appear to matter much whether one or both other judges are of the opposite political party from the opinion author. This suggests that an authoring judge will be just as influenced in choosing citation patterns by the presence a single judge from another party as by the presence of two judges from another party.

Overall, the data appear consistent with the pattern that would be

13. When we ran the same regression as in Table 3 but omitted those fixed-effects variables, the proportion of Republicans on the rest of the panel was statistically significant $(p<.05)$. 
expected on the basis of positive political or contextual theorieswhether that effect was from persuasion, collegiality, or pressure from other members of a panel. The larger magnitude and more statistically significant coefficient for the "same party" variable relative to the "opposite party" variable suggests two complementary possibilities. First, a judge may cite same-party legislative history to persuade other judges when both of those judges are of the same political party as the author. But as soon as one of the judges is of another political party, such citations may no longer be as helpful, tending to persuade one of the other judges but alienate the other. Especially if a potential citation is in fact not generally persuasive, a judge may worry that the oppositeparty panel member may act as a whistle-blower and expose the weak legislative history argument. Second, a judge may cite opposite-party legislative history to persuade other panel members that the position he is advocating is not based on his own ideology. An authoring judge may feel less need to demonstrate this when both of the other judges on the panel are of the same political party as he. There is thus less oppositeparty legislative history (and relatively more same-party legislative history) when a panel is politically unified.

We also ran probit regressions over various subsets of the cases in circuit courts. Table 5 isolates majority and nonmajority opinions. For majority opinions, which constitute most of the sample of Table 4, the results track the results of Table 4 . For nonmajority opinions, the variable representing the case in which the two other judges are of the same political party as the opinion author was not statistically significant, but the variable representing the case in which the two other judges are of the opposite political party was statistically significant $(p<.05)$. That is, the ideology effect does manifest itself (and overwhelms any desire a judge may have to mask the ideology in an opinion) in cases in which a judge is presenting a view different from two judges of the opposite political party. Meanwhile, with nonmajority opinions as with majority opinions, the variable representing the percentage of judges on the rest of the circuit with the same party affiliation as the author is significant $(p<.01)$ in the expected direction. These findings for nonmajority opinions may reflect that judges writing these opinions in circuit court panels have failed to persuade the other judges on the panel and are focusing on a different audience: the other members of the circuit, who might grant en banc rehearing. In focusing on this audience, a nonmajority authoring judge may wish to cater to the preferences or biases of those judges, whether or not those judges are in the same party as he. 





3.2.4. The Decision to Cite Legislative History. The analyses above focus on citation patterns given a decision to cite legislative history rather than on the decision whether to cite legislative history at all. A decision to forgo legislative history may be attributable to various causes, including judicial philosophy about legislative history. For example, Republicanappointed judges are generally thought to favor textualism - to interpret statutes using only the text of the statute and not legislative historywhile Democrat-appointed judges are thought to favor more direct indices of legislative intent such as legislative history.

To identify any ideology, contextual, or judicial philosophy effects on the decision to cite legislative history, we measured expected panel compositions on the basis of a matched set of appellate panels (without regard to whether or not legislative history was cited) ${ }^{14}$ against the observed panel makeup of our main set of cases citing legislative history. If the matched set and main set of panel composition numbers are significantly different, then we may conclude that political-ideological preferences, contextual effects, or judicial philosophies with regard to legislative history may affect the initial decision whether to cite legislative history. Table 6 reports this comparison and p-statistics based on $\chi^{2}$ tests.

With unified Democrat and unified Republican panels, the differences between the main and the matched sample proportions are significant. Unified Democrat panels represented 13.7 percent of observed cases in the main sample (cases citing legislative history) but only 12.1 percent of cases in the matched sample $(p<.01)$. The difference between expected and observed cases among unified Republican panels was more dramatic and in the opposite direction: unified Republican panels constituted 14.0 percent of the main sample but 17.9 percent of the cases in the matched sample $(p<.01)$. We observe similar tendencies when examining mixed panels. If one Republican appointee sat with two Democrat appointees, the panel was more likely than expected to cite legislative history $(p<$ $.01)$, while if two Republicans sat with one Democrat, the panel was less likely than expected to cite legislative history $(p<.01)$.

Breaking down the mixed panels by opinion author is especially in-

14. We constructed matched samples of both appellate and district court cases by downloading and analyzing, using the same computer program that we used for cases citing Congressional Record, an effectively random set of comparison cases from the same time period. The matched sample consisted of all cases beginning on page $100,200, \ldots$, or 900 of the Federal Supplement or Federal Reporting series (including successor series, such as F.3d). This produced a total of 1,714 appellate and 1,077 district court cases. 
Table 6. Expected and Observed Cases Citing Legislative History: Three-Judge Appellate Panels

\begin{tabular}{|c|c|c|c|}
\hline Panel Configuration & $\begin{array}{c}\text { Expected } \\
\text { Proportion: } \\
\text { Matched Sample }\end{array}$ & $\begin{array}{c}\text { Observed } \\
\text { Proportion: } \\
\text { Main Sample }\end{array}$ & $p$-Statistic \\
\hline $\begin{array}{l}J_{\mathrm{D}}, J_{\mathrm{D}}, J_{\mathrm{D}} \\
J_{\mathrm{R}}, J_{\mathrm{R}}, J_{\mathrm{R}} \\
J_{\mathrm{D}}, J_{\mathrm{R}}, J_{\mathrm{R}} \\
J_{\mathrm{R}}, J_{\mathrm{D}}, J_{\mathrm{D}} \\
\text { Split panels by opinion } \\
\quad \text { author: }\end{array}$ & $\begin{array}{l}.121 \\
.179 \\
.389 \\
.312\end{array}$ & $\begin{array}{l}.137 \\
.140 \\
.366 \\
.358\end{array}$ & $\begin{array}{r}.0049^{*} \\
<.0001^{*} \\
.0058^{*} \\
<.0001^{*}\end{array}$ \\
\hline $\begin{array}{l}J_{\mathrm{D}}{ }^{\mathrm{a}} J_{\mathrm{R}}, J_{\mathrm{R}} \\
J_{\mathrm{D}}, J_{\mathrm{R}}, J_{\mathrm{R}} \\
J_{\mathrm{R}}, J_{\mathrm{D}}, J_{\mathrm{D}} \\
J_{\mathrm{R}}, J_{\mathrm{D}},{ }^{2} J_{\mathrm{D}}\end{array}$ & $\begin{array}{l}.130 \\
.259 \\
.114 \\
.198\end{array}$ & $\begin{array}{l}.144 \\
.221 \\
.105 \\
.254\end{array}$ & $\begin{array}{l}.013^{*} \\
<.0001 * * \\
.079 \\
<.0001 *\end{array}$ \\
\hline
\end{tabular}

Note. $N=1,714$ for the matched sample and 3,252 for the main sample.

-Authoring judge.

$p<.05$.

${ }^{* *} p<.01$.

formative. First, ideology of the opinion author matters. For panels with one Democrat and two Republicans, cases in which the author is the Democrat are overrepresented in cases citing legislative history relative to the matched sample, and cases in which one of the Republicans is an author are underrepresented. Similarly, with the one-Republican, twoDemocrat panels, cases in which a Democrat is the author are overrepresented, and cases in which the Republican is the author are underrepresented. Within each panel type, the difference in the proportion of cases with a Democrat opinion author is statistically significant $(p<$ .01 ). Thus, although we saw in Table 3 that author ideology in threejudge panels does not affect the pattern of citations to legislative history given the decision to cite legislative history, author ideology appears to matter in the decision whether to cite legislative history at all.

Meanwhile, the split-panel data also show that in the decision to cite legislative history, the party of the nonwriting judges on appellate panels affects decisions whether to cite legislative history. Democrat opinion authors cited legislative history somewhat more than expected when sitting with two Republican appointees $(p<.05)$; such panels constituted 14.4 percent of the main sample and 13.0 percent of the matched sample. The difference was somewhat more dramatic when a Democrat opinion author was sitting with only one Republican $(p<.01)$; such panels constituted 25.4 percent of the main sample and just 19.8 percent of the 
Table 7. Expected and Observed Cases Citing Legislative History, by Majority of Judges in Circuit: District Courts

\begin{tabular}{lccccc}
\hline & \multicolumn{2}{c}{$\begin{array}{c}\text { Republican } \\
(p=.78)\end{array}$} & & \multicolumn{2}{c}{$\begin{array}{c}\text { Democrat } \\
\left(p<.0001^{*}\right)\end{array}$} \\
\cline { 2 - 3 } \cline { 5 - 6 } & Main & Matched & & Main & Matched \\
\hline Democrat author $(p=.26)$ & 31.0 & 31.8 & & 17.1 & 18.9 \\
Republican author $\left(p<.0001^{*}\right)$ & 39.5 & 39.9 & & 12.4 & 9.4 \\
\hline
\end{tabular}

Note. $N=1,416$ for the main sample of Republican circuits and 593 for the main sample of Democrat circuits; $N=772$ for the matched sample of Republican circuits and 305 for the matched sample of Democrat circuits. Evenly divided circuits were counted as Republican. Values represent the degree to which the cell is overrepresented (underrepresented) in the main sample relative to the matched sample.

${ }^{*} p<.01$.

matched sample. The comparison between these differences is statistically significant $(p<.05)$. Similarly, Republican opinion authors cited legislative history somewhat less than expected randomly when sitting with two Democrat appointees, but even more rarely when sitting with only one Democrat appointee on the panel. This difference, however, is not statistically significant.

We see similar effects on the district court level. Consider Table 7. Comparisons within columns reveal ideology effects, and comparisons within rows reveal hierarchy effects. In district court judges' decision whether to cite legislative history, we observe a statistically significant ideology effect, but only within Democrat-controlled circuits, and we observe a significant hierarchy effect, but only with Republican opinion authors. These findings appear consistent with the general theories that Democrats place more weight on legislative history than do Republicans and that district court judges seek to use legislative history to persuade their superiors. Presumably, some legislative history is of such importance that almost all judges will cite it, while other legislative history is more marginally relevant. If the primary function of a citation to marginal legislative history is to persuade, then one would expect that such citation would be especially likely to increase when a judge who generally does not think it to be particularly relevant worries that the reviewing judges might find it relevant. Thus, unsurprisingly, it is the table cell with Republican authors and Democrat-controlled circuits that is the greatest outlier in the data. 


\section{DISCUSSION}

Although judicial philosophy appears to influence decisions whether to cite legislative history, with Democrats more likely than Republicans to cite it, in the cases in which legislative history is cited, opinion-writing judges exhibit little ideological bias in determining which citations to include. A Republican-appointed judge is not more likely to cite Republican legislators than is a Democrat-appointed judge. Judges, however, appear to consider the political-ideological preferences of the judges who will review or be part of the decision-making process in determining which legislators to cite. For district court judges, that means looking to the makeup of the circuit court; for circuit court judges, that means looking to the makeup of the other members on the panel and of the remainder of the circuit.

While we find political-contextual effects to be stronger than the ideology effects of the judge writing the opinion, our study does not suggest that these factors matter more than traditional legal model factors in statutory interpretation and the use of legislative history. Indeed, differences between Democrats and Republicans in the decision whether to cite legislative history is consistent with the observation that textualists should be more skeptical of legislative history. Our coefficient estimates of the impact of political ideology and context on citations to legislative history, meanwhile, are sufficiently low to indicate that we are identifying deviations in citation patterns of modest magnitude. Perhaps citation patterns are affected only in a subset of politically relevant cases that we do not specifically identify in this analysis. It may also be that the effect is greater than we document here but that we cannot measure it because our coding mechanisms are too rough. After all, Democrat legislators sometimes make floor statements that support Republican positions and vice versa.

It might at first appear that our identification of hierarchy and panel effects could be merely a by-product of the general finding of attitudinal and positive political theory that judges tend to reach case outcomes consistent with their presumed ideologies in particular cases. For example, some judges, more likely Democrat appointees than Republican appointees, might prefer a liberal policy outcome to a conservative policy outcome in the interpretation of a statute. The floor comments of Democrats may be more likely on average than those of Republicans to support such an interpretation. On this theory, results-oriented voting would cause selective citation, and the selective-citation evidence in the hier- 
archy effect and panel effect occurs solely because the characteristics of other judges affect the vote outcome of the opinion author. Selective citation thus occurs not so much because legislative history has genuine persuasive force but because it follows naturally from a case outcome that is chosen by the panel as a whole.

If this theory were correct, our study should have identified not only hierarchy and panel effects but also a strong effect of opinion author ideology. As noted above, Sunstein, Schkade, and Ellman (2004, p. 305) conclude that the political orientation of a judge has about the same effect on his vote on the outcome of a case as the political orientations of other judges. If selective citation were a mere by-product of voting on case outcomes, we would expect the authoring judge's political affiliation to be roughly as important as the political orientations of other judges. That prediction finds little support from the data. Indeed, the negative signs on the statistically insignificant $J_{R}$ variables in Tables 2 and 3 suggest that if there is any ideology effect, at least placing aside nonmajority opinions, it may well run counter to what one would predict on the basis of judges' presumed political preferences.

Although our conclusion on this point must be tentative, the data suggest that legislative history citations reflect more than the judge's decision about how to vote on the case outcome. Observed legislative history citations, as well as those that are omitted, may represent attempts to persuade other judges. Even if this hypothesis is true, it does not explain just what role legislative history plays. Perhaps judges cite floor comments of the party of the judges they wish to persuade because they believe that those judges will be sympathetic to the types of arguments made by same-party legislators. Or perhaps legislative history serves merely as a heuristic device. A judge may expect colleagues to give relatively great credence to legislative history from a legislator who shares the same party identification because of the values and policy expectations associated with that party identification. On a panel whose nonauthoring judges are Republican, an authoring judge may cite $\mathrm{Re}$ publican legislative history in the hope that, regardless of the content and relevance of the citations, the other panel members will be more willing to accept an opinion that cites to Republican legislative history.

The data also cannot distinguish the persuasion hypothesis from several closely related alternatives. Perhaps a judge selecting legislative history to cite makes the choice in part to please other judges, not so much because he is actively worried about another judge's vote but simply because of a desire to write a judicial opinion that the other judge will 
admire. On other occasions, a judge might include some legislative history in an opinion specifically suggested by another member of the panel, perhaps after the first draft of an opinion has been circulated. In this case, one might describe the inclusion as reflecting not so much an attempt at persuasion as succumbing to coercion. Regardless of which conclusion one may draw, the pattern of legislative history citation appears at least to suggest that judges care not only about the outcomes and holdings of cases but also about the reasoning.

\section{CONCLUSION}

This study differs from past judicial politics studies by quantifying more microanalytic aspects of legal reasoning within judicial opinions. We found evidence of panel and hierarchy effects in citation to legislative history, effects that appear related to the political-ideological identification of judges who review or are members on a panel with the authoring judge. Specifically, we find that the higher the proportion of Republican appointees in the reviewing court or sitting on the same three-judge panel, the higher proportion of legislative history citations will be to Republican legislators, regardless of the political affiliation of the authoring judge, and vice versa for Democratic appointees and Democratic legislators. The pattern of the data appears broadly consistent with positive political and contextual theories of judicial decision making.

There are other possible directions for further research. First, consideration of the briefs filed in particular cases might further illuminate judges' reasoning. For example, it would be possible to test whether citations to sources not cited in briefs are associated with judges' presumed ideologies. Eliminating selection effects from briefs, we may see stronger political-ideological forces at play in the use of legislative history by judges. Second, quantitative analysis of reasoning might be combined with quantitative analysis of whether the results in cases were liberal or conservative. Data on whether particular decisions reached a liberal or conservative result might allow for clearer conclusions about the reasons for selective citation. Finally, it may be that the Supreme Court plays a different game with legislative history as it attempts to influence congressional responses to the Court's decision. A check on the political-ideological context between the Supreme Court and Congress may reveal unique strategies not captured by district and appellate court analyses. We leave these projects for future work. 


\section{REFERENCES}

Cameron, Charles M., and Craig P. Cummings. 2003. Diversity and Judicial Decisionmaking: Evidence from Affirmative Action Cases in the Federal Courts of Appeal, 1971-1999. Unpublished manuscript. Columbia University, Department of Political Science, New York.

Cohen, Linda R., and Matthew L. Spitzer. 1994. Solving the Chevron Puzzle. Law and Contemporary Problems 1994(spring):65-110.

Cross, Frank B., and Emerson Tiller. 1998. Judicial Partisanship and Obedience to Legal Doctrine: Whistleblowing on the Federal Courts of Appeals. Yale Law Journal 107:2155-76.

Epstein, Lee, and Jack Knight. 1997. The Choices Justices Make. Washington, D.C.: CQ Press.

Eskridge, William N., Jr., and John Ferejohn. 1992. The Article I, Section 7 Game. Georgetown Law Journal 80:523-64.

Farhang, Sean, and Gregory Wawro. 2004. Institutional Dynamics on the U.S. Court of Appeals: Minority Representation under Panel Decisionmaking. Journal of Law, Economics, and Organization 20:299-329.

Gely, Rafael, and Pablo T. Spiller. 1990. A Rational Choice Theory of Supreme Court Decisions with Applications to the State Farm and Grove City Cases. Journal of Law, Economics, and Organization 6:263-300.

Jacobi, Tonja, and Emerson H. Tiller. 2007. Legal Doctrine and Political Control. Journal of Law, Economics, and Organization 23:326-45.

McKibbin, Caroll. 1997. Roster of United States Congressional Officeholders and Biographical Characteristics of Members of the United States Congress, 1789-1996. Study No. 7803. Ann Arbor, Mich.: Inter-university Consortium for Political and Social Research.

Pinello, Daniel R. 1999. Linking Party to Judicial Ideology in American Courts: A Meta-Analysis. Justice Systems Journal 20:219-54.

Revesz, Richard L. 1997. Environmental Regulation, Ideology, and the D.C. Circuit. Virginia Law Review 83:1717-72.

Scalia, Antonin. 1997. A Matter of Interpretation: Federal Courts and the Law. Princeton, N.J.: Princeton University Press.

Schanzenbach, Max, and Emerson H. Tiller. 2007. Strategic Judging under the United States Sentencing Guidelines: Positive Political Theory and Evidence. Journal of Law, Economics and Organization 23:24-56.

Segal, Jeffrey A., and Harold J. Spaeth. 1993. The Supreme Court and the Attitudinal Model. Cambridge: Cambridge University Press.

Smith, Joseph L., and Emerson H. Tiller. 2002. The Strategy of Judging: Evidence from Administrative Law. Journal of Legal Studies 31:61-82.

Spiller, Pablo T., and Matthew Spitzer. 1992. Judicial Choice of Legal Doctrines. Journal of Law, Economics, and Organization 8:8-46.

Spiller, Pablo T., and Emerson H. Tiller. 1996. Invitations to Override: Con- 
gressional Reversal of Supreme Court Decisions. International Review of Law and Economics 16:503-21.

Sunstein, Cass R., David Schkade, and Lisa M. Ellman. 2004. Ideological Voting on Federal Courts of Appeal: A Preliminary Investigation. Virginia Law Review 90:301-53.

Tiller, Emerson. 1998. Controlling Policy by Controlling Process. Journal of Law, Economics, and Organization 14:114-35.

Tiller, Emerson H., and Pablo T. Spiller. 1999. Strategic Instruments: Legal Structure and Political Games in Administrative Law. Journal of Law, Economics, and Organization 15:349-77.

Wald, Patricia M. 1983. Some Observations on the Use of Legislative History in the 1981 Supreme Court Term. Iowa Law Review 68:195-216. 